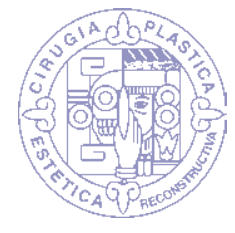

EDITORIAL

doi: $10.35366 / 98337$

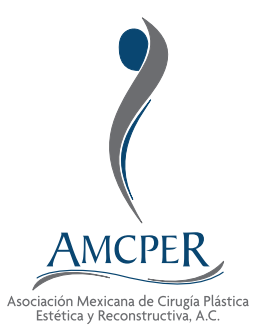

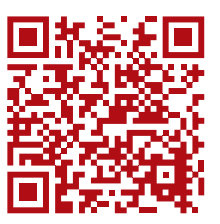

\section{La cirugía plástica en la nueva normalidad}

\author{
Plastic surgery in the new normal
}

Dra. Estela Vélez-Benítez*

* Cirujano plástico

y reconstructivo. Integrante del Comité de Seguridad de la Asociación Mexicana de Cirugía Plástica, Estética y Reconstructiva, A.C.
No es la especie más fuerte la que sobrevive, ni la más inteligente, sino la que responde mejor al cambio.

Charles Darwin

$\mathrm{E}^{\mathrm{s}}$ stamos viviendo la pandemia de COVID-19 que no sabemos cuánto durará, posiblemente hasta la óptima cobertura de la vacuna, por este motivo debemos aprender de esta enfermedad y adaptarnos al nuevo estilo de vida.

Desde marzo de 2020 la Organización Mundial de la Salud clasificó como pandemia a la infección ocasionada por SARSCoV-2 (WHO \& Situation, 2020). A más de un año de darse a conocer este virus, aún no tenemos la cura para esta enfermedad; sin embargo, día a día se van conociendo las características, manifestaciones clínicas, complicaciones y posibles tratamientos y continuamos en la búsqueda de la mejor opción de prevención.

En la actualidad, las autoridades han emitido recomendaciones aprendidas de otras epidemias, y una de ellas es la cuarentena; no obstante, por cuestiones económicas no podemos parar y ante el miedo -sinónimo de ignorancia- tenemos que aprender a trabajar y a adaptarnos a un nuevo estilo de vida para continuar con nuestras labores. Por este motivo, en todas las áreas de trabajo (y la cirugía plástica no es la excepción), se debe buscar la manera de adaptarse a esta «nueva normalidad». Es indispensable conocer las medidas de pro-

tección y desinfección para nuestras oficinas, consultorios, áreas de tratamiento y quirófanos para protección de nuestros pacientes, personal de trabajo, familiares y del personal médico.

Es indispensable el uso de cubrebocas y equipo de protección ocular para disminuir el riesgo de transmisión, que reporta una reducción hasta de $86 \%$ al estar en contacto con nuestros pacientes; mantener la distancia de 1.5 metros disminuye el riesgo de contagio dos veces por cada metro de espacio; el lavado adecuado y constante de manos; el uso de agentes químicos como el alcohol al $75 \%$ o el hipoclorito de sodio al $1 \%$ y la detección oportuna del virus en el preoperatorio de nuestros pacientes, siendo éstas las más relevantes dentro de la serie de medidas de prevención.

Por lo anterior, esta pandemia nos obliga a desarrollar estrategias, guías y protocolos para disminuir el riesgo de contagio, complicaciones y muerte, al brindar la oportunidad para realizar cambios y mejorar nuestra actividad quirúrgica electiva con protección y un adecuado equipo de trabajo, tomando las mejores decisiones para nuestros pacientes.

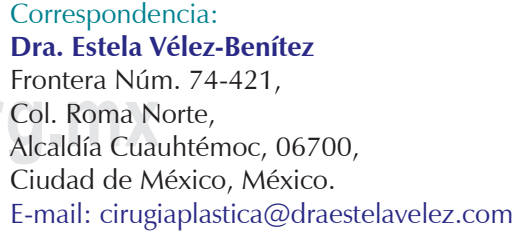

Citar como: Vélez-Benítez E. La cirugía plástica en la nueva normalidad. Cir Plast. 2020; 30 (3): 143. https:// dx.doi.org/10.35366/98337 